\title{
Determining Indicators Of Happiness Index Among University Staff
}

\author{
Khairunesa Isa, Lutfan Jaes, Zahrul Akmal Damin, Azmi Abdul Latiff, Abdul Halim Abdul \\ Rahman, Naim Maslan, Abu Khari A'ain, Siti Solehah Tenah
}

\begin{abstract}
Besides playing their role to produce competent graduates, university staff have the commitment to develop their career as their final objective. While determining the achievability of the objectives, university staff are exposed to various situations that could potentially cause emotional imbalance. This could lead to unhappiness among them. Henceforth, a research on psychosocial aspect and work environment ecology needs to be carried out to identify indicators that help to improve the happiness of the university staff that directly affects the performance of the organization. A total of 535 respondents were randomly selected to answer a questionnaire which was based on the Model of Happiness. The benchmark used to construct the Happiness Index among Staff at University $A$ was based on the measurement used in the World Happiness Index. Cumulative Index showed that the staff happiness was at a moderate level with a score value of $72 \%$. The finding serves as a platform for University $A$ to scrutinize and improve elements needed to create work life balance among academic and administrative staff.
\end{abstract}

Index Terms: emotional imbalance, happiness indicator, job environment and work life balance.

\section{INTRODUCTION}

It is without doubt that in facing challenges to achieve organizational KPI, there will be staff who feel unhappy at their workplace. This could potentially lead the demands of work-life balance. (Rashid et al., 2012). Happiness at workplace can be defined as a situation in which staff are in the state of well-being and feel happy in carrying out their jobs (Wesarat 2014). Such a situation is indispensible to an organization as happy staff will lead to better productivity (Wok and Hashim, 2015). Moreover, workers who are happy with their work environment will catalyze the performance of their organization (Hongyi Hung, 2016).A happy emotion will influence an individual to have a happy life and most of the time happiness is gained through experience (Stoia, 2015). Thus, it could be said that the environment in an organization gives a major impact to the

Revised Manuscript Received on April 19, 2019.

Khairunesa Isa, Centre for Curriculum and Public Studies, Universiti Tun Hussein Onn Malaysia, Batu Pahat, Johor, Malaysia.

Lutfan Jaes, Centre for Curriculum and Public Studies, Universiti Tun Hussein Onn Malaysia, Batu Pahat, Johor, Malaysia.

Zahrul Akmal Damin, Centre for Curriculum and Public Studies, Universiti Tun Hussein Onn Malaysia, Batu Pahat, Johor, Malaysia

Azmi Abdul Latif, Centre for Language Studies, Universiti Tun Hussein Onn Malaysia, Batu Pahat, Johor, Malaysia

Abdul Halim Abdul Rahman, Registrar, Universiti Tun Hussein Onn Malaysia, Batu Pahat, Johor, Malaysia

Naim Maslan, Registrar, Universiti Tun Hussein Onn Malaysia, Batu Pahat, Johor, Malaysia

Abu Khari A'ain, Faculty of Electrical and Electronic Engineering,

Siti Solehah Tenah, Research Management Centre, Universiti Tun Hussein Onn Malaysia, Batu Pahat, Johor, Malaysia Universiti Tun Hussein Onn Malaysia, Batu Pahat, Johor, Malaysia

work ecology of its staff particularly in contributing to their happiness.

\section{PROBLEM STATEMENT}

Each individual has different level of happiness and the difference is influential to one's life physically and mentally (Kraise, 2014). According to Sulaiman (2014) staff are not happy at a workplace when there is a communication gap between the top management and general staff, nonappreciation of employers on ideas by their employers, lack of attention on staff welfare and non-appraisal from the employers to contributions made by their workers. The level of happiness among employees will also influence their emotion which could lead to stress and consequently affect the staff behavior in the organization (Rashid et al., 2014).

In the World Happiness Index, Malaysia is positioned in the third happiest country with an index score of 6.084 . Singapore is the world's happiest country (index score 6.572) and Thailand is in the second place with a mean score of 6.424. Nevertheless, 30 percent of Malaysians are suffering from some mental illnesses. Arumugam (2016) explained that three of every Malaysian adults are facing mental illness which are caused by a variety of situations which mostly are originated from pressure and feeling of unhappiness in life. Meanwhile, the National Health Morbidity (Kosmo Online, 2018) research report stated every three of ten adults aged more than 16 years old are suffering from various mental illnesses. These mental illnesses consist of factors such pressure, depression, schizophrenia and conflict.

A pilot research by University A shows that inconsistencies in work procedures in university frequently happens particularly when there is a change of leadership in the top management. This causes confusion among the staff and makes them feel burdened to learn new processes and work procedures while they have yet to master the previous and existing ones. Having to learn new things in a short period of time could cause staff to be easily suffering from tension which finally leads them to face the problem of stress.

According to Lunbergand Cooper (2011), the effect of depression could cause stress which will destabilize an individual's level of happiness and adversely affect the performance of his organization. Among other effects of unhappy workers are they will easily become sad, nervous, feel empty, hopeless, feel not appreciated, lose their temper and restless. Meanwhile, Lyubomirsky, King and Diener

Published By:

Blue Eyes Intelligence Engineering 
(2005) and Pressman and Cohen (2005) are of the opinion that staff who are unhappy while carrying out their duty can be compared to individuals who are face depression, mental illness and always feel inferior and avoid themselves from involving in social activities. What is more worrying is such staff may lose their motivation to work, have difficulty to focus, lose their appetite and may even attempt to commit suicide(Rashid et al., 2012).Henceforth, this study attempts to determine the indicators that can be employed as the baseline in constructing University A's Staff Happiness Index that will serve as an alternative to assist its staff to enjoy a work-life balance.

\section{A. Research Objective}

i. To determines indicators that contribute to staff happiness at University A.

ii. To construct UTHM's Staff Happiness Index

\section{LITERATURE REVIEW}

The definition of happiness is subjective (Fisher, 2010; Selignman, 2005 and Carr, 2004). Generally, the term happiness is used interchangeably with the words joyfulness, peacefulness, wellness and quality life (Fisher, 2010). This is because conceptually all the terms have almost identical values and measurement which provide positive impact to life that will lead to self improvement. For an example, according to Azizah et al., (2014), wellness refers to a dynamic process that provides added values to human that will change their lives to the better or otherwise. According to Hassan (1983), in order to achieve the true meaning of happiness in the world, one needs to have a good mental health. This is because his happiness is influenced by his interpretations that are produced by his mental.

In aiming to achieve happiness in the life of staff, Gavin and Masson (2004) suggested that one should work in a good organization. Most studies revealed that majority of the staff who are suffering from pressure and having the feeling of unhappiness, are influenced the character of the organization including the aspects of leadership and work environment (Fisher, 2010). As such, organizational behavior can be used as the main element to determine the level of happiness at an organization. This is because such feeling does not only affect them psychologically but could also impact the company's performance. Another research by Ranstad's Workmonitor in the year 2018 showed that staff feel comfortable when working at the office because the office atmosphere provides encourages them to be more focused. The same study showed that 90 percent of the work force in Malaysia feel comfortable and happy when given the freedom to make decisions besides having a flexible work schedule.

\section{A. Indicator for Determining Happiness among Staff}

Happiness can defined as combination of frequency of positive and negative responses that affects satisfaction in the life of human (Myers \& Diener, 1995; Diener et al., 1999). On the other hand, Jain et al., (2012) stated that happiness emerges from pleasurable emotion and feeling besides being positive on a certain matter. Happy individuals are inclined to provide aid to other individuals, be creative, pro social, love to do charity and healthy (Diener \& Dean, 2007). Individual who easily feel happy are able to avoid themselves from becoming stressful, feeling under pressure and become hypertension (Amirullah, 2017).

Factors that influence the level of work satisfaction may differ for every single staff. Generally, work satisfaction is influenced by various factors including wages received, opportunity for promotion, quality of supervision and fellow staff (Smith, Kendall and Hullin, 1969). Each factor however, gives different impact on work satisfaction for every individual. The difference is influenced by personal factor that is how each individual defines work satisfaction. According to Mitchell (1979), high wage and challenging job are important factors that lead to staf' work satisfaction. It should be noted however that in the context of ageing staff or those who are not technologically literate, working in a technology-oritented workplace adds more pressure to them.

There are individuals who define happiness at workplace as something that is physically visible such as ergonomic work environment (Zafir, 2010). Nevertheless, there are also many who define happiness at workplace can be achieved in a more subjective context such as interaction among fellow staf (Wesarat, Majid and Sharif, 2015; Staib, 2009 and Suojanen, 2012), work satisfaction (Meriam, 2017; Ariati, 2010 and Alfarisi, 2010), good organizational management, (Mindtools, 2009), task activities, organizational culture (Wesarat, Majid dan Sharif, 2015), effective leadership (Muda et al., 2018) and few others.

Successful personal development also shows that an individual has successfully displays a good performance in carrying out his duties. According to Ruvendi (2005), work performance can be achieved when an individual uses all his ability, strength and effort that he has. This is in line with the Maslow's Needs Hierarchy Theory (1943) which states that an individual will feel more satisfied and complete when he is able to fulfill his personal need privately. Wesarat et al., (2014) also supported the findings by stating that there exist a relation between work activity and self development and happiness at workplace.

Research by JobStreet.com (2018) discovered that factors such work location and condition as well as organizational reputation are the main reasons behind staff satisfaction at workplace. In fact, many Malaysians feel happy with the atmosphere at workplace compares to their home. This shows how influential the factors are on staff happiness. Similar to the opinion, Zafir (2010) stated that it is important to establish an ergonomic workplace environment as it could reduce stress in an organization. According to Dul and Newmann (2009), ergonomic does not only focus on occupational safety and health but also supports business strategy in order to maintain competitiveness in the organization.

In emphasizing the important of ergonomic workstation, Holcroft and Punnetts (2009) added that an ergonomic workplace environment influence human resource psychologically and biologically. In tandem with this, Obiora E. Iyi (2015) successfully proved in his research that 
staff's environment can help to mould excellent staff.

The Happiness Model explains that the feeling of happiness is subjective. The model comprises three main indicators that mould happiness at workplace namely individual, organizational and social. Individuals who feel that they have the stability in all three indicators for determining happiness at workplace. In the context of individual, a person will feel happy when he is satisfied with his workplace environment, enjoys career development, possesses skills relevant to his job specifications and able to adapt. All these factors have a very strong relationship with the level of happiness of staff as they are practiced at the individual level.

The individual factor is stated as the main element that affects individual's happiness as it involves thought, personality and condition of an individual. Elements of positivity and negativity possess by the staff leave a very strong effect on their work environment. Positive elements will produce individuals who are more motivated in carrying out their responsibilities. Having motivated staff will continuously improve the performance of an organization.

Furthermore, organizations have been found to be the sources for producing committed and loyal staff. Even though commitment and loyalty come from within individuals, the organization is responsible in moulding staff commitment and loyalty through various initiatives. Among the initiatives that can be carried are by providing benefits to staff, tolerance between employers and staff and leadership style practiced in the organization (Muda et al., 2018). Organization support involves organizational management of the staf in the context of helping to manage the staff in the current work atmosphere and improve their work performance that is needed for their future career development.

Organizations should not only focus on achieving their aims. Instead, they should also take into account the performance of their staff and their career development The physical atmosphere at workplace is capable of influencing the staff motivation to work. It is the role of the organizations to ensure work atmosphere such as level of noise, level of temperature and air circulation at workplace are capable of providing comfortability to the staff. Even though the physical atmosphere required by every staff may vary depending on their needs, the organizations are capable of providing almost similar comfortability to each of their staff.

Interactivity and social relationship elements are influential in determining the happiness of individuals. (Siska and Ami, 2014; Fisher, 2010 and Carr, 2004). In this context, the role of each member in the support system is capable to affect the behavior and emotion of the staff. Not only referring to office colleagues and social friends, family members were found to give more impact to staff happiness. According to Meriam (2007) relationship with other individuals in similar surrounding either formal or informal is strongly believed to have influence on individual happiness. Thus, it could be said that each factor in human ecology has the possibility to determine staff happiness. Figure 1 shows the ecological factors that determined staff happiness index at the university where the research was conducted.
Figure 1 : Research Framework

Figure 1 : Research Framework

\begin{tabular}{|l|}
\hline Individual Factor \\
\hline Organizational Factor \\
\hline Social Factor
\end{tabular}$\longrightarrow \begin{gathered}\text { Staff } \\
\text { Happiness Index }\end{gathered}$

\section{METODHOLOGY}

\section{A. Design and Sampling}

The research was a descriptive survey. A total of 535 respondents were selected through simple random sampling from the total population. The samples comprised academicians and administrative staff of University A.

\section{B. Research Instrument}

This descriptive survey employed observation and questionnaire as research instruments. The questionnaire was used to identify and determine indicators that contribute to staff happiness at University A by focusing on three factors namely individual, social and organizational. Likert scale with 4 option answers was used to evaluate a statement based on score distribution as presented in Table 1 . Besides, it was also used to avoid respondents from giving answers such as 'unsure' or' disagree'. The frequency of the respondents to choose option at scale 3 such as 'unsure' and 'disagree' will put the credibility of the research in doubt.

Table 1 : Likert Scale for Happiness Level

\begin{tabular}{|l|c|}
\hline \multicolumn{1}{|c|}{ ITEM } & SCALE \\
\hline Strongly Disagree & 1 \\
\hline Disagree & 2 \\
\hline Agree & 3 \\
\hline Strongly Agree & 4 \\
\hline
\end{tabular}

\section{B. Data Analysis for Developing}

Happiness Index is one of the instruments that can be used to measure individual or collective happiness at workplace. In determining the level of happiness among staff at University A, a Staff Happiness Index would be developed based on the measurement used in the World Happiness Index. Among the agencies in Malaysia that have used the index are Local Governments in the report entitled World Happiness Index : Malaysia's Initiative with Local Authorities under the Ministry of Housing and Local Government (2012).

In the beginning, the data was analyzed descriptively using frequency count, percentage and median values for each variable using the SPSS 2.0 software. The descriptive analysis was carried out to determine indicators of staff happiness at University A. According to World Happiness Index, the method to be used in developing a staff happiness index should take into account the total of median values for each construct for every variables investigated. The measurement of the happiness index at University A was based on the three happiness levels namely happy, moderate at unhappy as presented in Table 2 . 
Table 2 : Happiness Scale

\begin{tabular}{|c|c|}
\hline Score Value & Happiness Level \\
\hline$>-80 \%$ & Happy \\
\hline $41-79 \%$ & Moderate \\
\hline$<-40 \%$ & Unhappy \\
\hline
\end{tabular}

As for the index development, there are four steps employed:-

Step i :total the median value for each variables measured;

Step ii multiply the number of items with the number of scales;

Step iii divide the total media in Step i with Step ii

Step iv multiply the score in Step iii with 100.

\section{RESULTS AND FINDINGS}

The development of the index was carried out in stages based on the research variable indicators namely individual, organization and social. This is presented in Table 3.

Table 3 : UTHM Staff Happiness Index

\begin{tabular}{|c|l|c|}
\hline Variable & \multicolumn{1}{|c|}{ Construct } & $\begin{array}{c}\text { Happiness } \\
\text { Index }\end{array}$ \\
\hline \multirow{5}{*}{ Individual } & Self satisfaction & $75 \%$ \\
\cline { 2 - 3 } & Working atmosphere & $75 \%$ \\
\cline { 2 - 3 } & $\begin{array}{l}\text { Self-development at } \\
\text { work place }\end{array}$ & $75 \%$ \\
\cline { 2 - 3 } & $\begin{array}{l}\text { Self-adaptability at } \\
\text { work place }\end{array}$ & $75 \%$ \\
\hline \multirow{5}{*}{ Organizational } & Organizational support & $75 \%$ \\
\cline { 2 - 3 } & $\begin{array}{l}\text { Working atmosphere at } \\
\text { workplace }\end{array}$ & $75 \%$ \\
\cline { 2 - 3 } & Task level & $55 \%$ \\
\cline { 2 - 3 } & Organizational policy & $65 \%$ \\
\hline \multirow{5}{*}{ Social } & Social atmosphere & $75 \%$ \\
\cline { 2 - 3 } & Social support & $75 \%$ \\
\cline { 2 - 3 } & $\begin{array}{l}\text { Relationship among } \\
\text { family, social and } \\
\text { individual }\end{array}$ & $80 \%$ \\
\hline & \multicolumn{2}{|c|}{ Total } \\
\hline
\end{tabular}

The cumulative index for University A's staff happiness showed that the staff happiness level was at the moderate level with the score value of $72 \%$. Such moderate score was perceived as a good start for University A in order to discover the current happiness level of the staff as it would influence the path to achieve the organizational objective. Such a finding would at least serve as a platform for University A to scrutinize and improvise by adding new elements that are needed in order to establish work-life environment among the academic and administrative staff.

The social factor showed the highest happiness score $(76 \%)$ followed by individual factor $(72.5 \%)$ and finally social factor $(67.5 \%)$. Relatively, the staff at University A feel happy when they are in the social context especially in the context of relationship involving family, social and individual. According to Naff (2012) and Snow (2013), positive relationship among friends at workplace is influential in determining staff happiness which finally leads to them feeling happy. What can be clearly seen is that staff need support in their surrounding that will help them the enjoy happiness at workplace.

For the individual factor, four of the constructs measured in developing happiness index for staff at University A included self-satisfaction, work atmosphere, selfdevelopment at workplace and adaptability at workplace. Generally, the cumulative for the individual factor was at the moderate level with the score of $72.5 \%$. All three constructs for this factor namely self satisfaction, work atmosphere and self development at workplace showed moderate score of $75 \%$. Despite this, the results indicated positivity within the respondents as they could control themselves physically and emotionally while on duty. The ability to control themselves individually will help to put conflicts and pressure while on duty to be under control.

Nevertheless, a difference of $10 \%$ in the score for self adaptability at workplace which was $65 \%$ was discovered. The condition of respondents who were newly hired staff at University A or respondents who were newly appointed to rotational posts was seen as a factor that contributed to the moderate score. In a situation when a respondent was appointed to a rotational university post while at the same time appointed as a fellow researcher of a research centrealso affected the respondent to adapt himself in carrying the burdens.

The cumulative index for staff happiness of the organizational factor also showed a moderate score of $67.5 \%$. Such a moderate score requires the organization to review the atmosphere and its ecological structure especially in the aspects of level of assignment and organizational policy. Meanwhile, improvements need to implemented to the organizational support and work atmosphere aspects in order to establish a good work atmosphere that is capable to create loyalty value within the staff that will encourage to continue working at University A with honesty. Head of departments at every office should play extra role in understanding and having the empathy with the workload of the respondents. The willingness of the heads to spend their time with their staff and listen to their grouses related to their work will somehow help the respondents to deal with the burden.

While still showing a moderate score for staff level of happiness, the social factor still displayed a high cumulative index of $76 \%$ compared to the organizational and individual factors. Such moderate score with the percentage that almost reached the happiness scale of $80 \%$ showed that the social factor including family and colleagues are really helpful in establishing atmosphere that creates happiness among staff. This is supported by the index scores for the relationship with family and social construct that reached the happiness level score of $80 \%$. Not confined to the psychological context but in fact the Islamic perspective also stated that 'the socializing aspect and relation between an individual with his surrounding' is indispensible in moulding his behavior, moral and identity (Zakaria et al., 2012).

Published By:

Blue Eyes Intelligence Engineering

\& Sciences Publication 


\section{CONCLUSION}

Overall, it can be said that the Staff Happiness Index at University A is only at moderate level as the three factors were found to be contributing to the staff happiness at different levels. Relatively, the relation elements either with friends or family members were discovered as the main factor to determine happiness among staff of University A. This was proven when all 'with friends' and 'with family' relationship items showed high scores. Explicitly, the findings shows that the staff of University A are unable to live independently and need to be surrounded with friends and family members in order to get happiness in the lives.

\section{ACKNOWLEDGMENT}

This research work is supported by the Project (vote : C072) supported by UTHM.

\section{REFERENCES}

1. Amirullah, M. (2017). Factor That Lead to Happiness at The Workplace Among Academician : A Case of UiTM. Melaca. UiTM Melacca City Campus.

2. Ariati Jati. (2010). Kesejahteraan Subjektif dan Kepuasan Kerja Pada Staf Pengajar (Dosen) di lingkungan Fakulti Psikologi Universiti di Ponegoro. Jurnal Psikologi Undip 8, No. 2.

3. Alfarisi.(2010). Hubungan Antara Kepuasan Kerja dengan Produktivitas Pada Guru. Skripsi Tidak Dipublikasikan. Pekanbaru. Fakultas Psikologi Universitas Riau.

4. Carr. (2004). Positive Psychology : The Science of Happiness and Human Strengh. New York : BrunerRoudledge.

5. Dean, B., Diener, R. B. (2007). Positive Psychology Coaching : Putting The Science of Happiness to Work for Your Client. Canada : John Wiley \& Sons.

6. Fisher, C.D. (2010). Happiness at Work. International Journal of Management Reviews, 12, 384-412. http://dx.doi.org/10.1111/1468-0297.00570

7. Gavin, J.H. and Masson, R.O., (2004). The Virtous Organization : The Value of Happiness in The Workplace. Organizational Dynamic. 33. 379-392.

8. Jaes, M.F., Isa, K., Ahmad, A.R., and Yusoff, R.M. (2018). The Analysis of Competency Based for Indonesian Construction Labourers. International Journal of Engineering and Technology (UAE). Open Access Volume 7, (4). 132-136.

9. Jain, A., Saeed, K., Arnaout, S. \& Kortum, E. (2012). The Psychosocial Environment at Work: An Assessment of the World Health Organization Regional Office for the Eastern Mediterranean. Eastern Mediterranean Health Journal 18(4): 325-331.

10. Lyubomirsky. (2007). The Benefit of Frequent Positive Affect : Does Happiness Lead To Success? Psychology Bulletin 131. (6).

11. Ministry of Housing and Local Government Tempatan (2012).

https://issuu.com/anwar_townplan/doc/0000004705presentation_2ᄀ_for_the_wtp_day_seminar

12. Meriam, O.M., (2017). Faktor-faktor Determinan Kebahagiaan Kerja Karyawan (Studi Kasus Pada PT. Bank Bukopin Tbk. Cabang Manado). Jurnal Riset Business dan Management. Vol. 5 (4). 611-630.

13. Muda, W.H.N.W., Libunao, W.H., Isa, K., Ahmad, A.R., and Yusoff, R.M. (2018). Leadership Capability Framework for the Construction Industry Leaders in Malaysia. International Journal of Engineering \& Technology, 7 (4.28), 505 -509.
14. Rashid, A. Sharif, M. Narina, A.S and Rosman, Y (2014). Personality and Happiness Among Academician in Malaysia. Procedia-Social and Behavioral Science. Vol. 116. 4209-4212.

15. Seligman. (2005). Authentic Happiness. UK: New York.

16. Siska, W. and Ami, W. (2014). Faktor-faktor Kebahagiaan Di Tempat Kerja. Fakulti Psikologi Universiti Islam Negeri Sultan Syarif Kasim Riau.

17. Suojanen, J. (2012). Work for Happiness-Theoretical and Empirical Study Defining and Measuring Happiness at Work. Thesis. Department of Education. University of Turku.

18. Wesarat, P, Sharif, M.Y, \& Abdul Majid. A. H. (2014) Conceptual Framework of Hapiness at the Workplace. Asia Social Science.

19. Wok, S. and Hashim, J. (2014). Communication Network Organizational Contact and Communication Power in Grooming Profesional for Career Success. Malaysian Journal of Communication. 219-242.

20. Zafir M.M., Nor Liza A., \& Noor Azuan H. (2013). Stress di Tempat Kerja: Isu Global Dalam Melestarikan Organisasi.: Global Issues in Organization Sustainability.

21. Zafir Mohd Makhbul, Sheikh Muhamad Hizam Sheikh Khairuddin \& Nur Sa'adah Muhamad. (2018) Hubungan stres pekerjaan dan produktiviti: Tinjauan terhadap pentadbir fakulti universiti penyelidikan. Journal of Social Sciences and Humanities 